\title{
RUSSIFICATION OF NON-ESTONIAN PUPILS IN TALLINN
}

\author{
Mart Rannut, Ülle Rannut
}

\begin{abstract}
In the article home languages, their qualities and use by pupils in grades 2 to 5 in Tallinn are analyzed. Two larger and more characteristic groups (Ukrainians and Belarusians) and two groups with Islamic backgrounds (Azerbaijanis and Tatars) were compared with the aim of analysing different language loss and preservation factors. Although Ukrainians and Belarusians form much larger ethnic groups within Estonia, they have not managed to preserve their language anywhere near as successfully as the Azerbaijanis and Tatars. Comparison of the data suggests that language preservation in Estonia and the ability to withstand Russification are most influenced by the degree of difference of the language from Russian and the religious difference from the Russian Orthodox faith (and Soviet era atheism). Home languages are characterised by their use mainly in the verbal form, with skills in the literary language generally low or even nonexistent. Languages are for the most part learned informally, primarily through communication with parents and/or grandparents. The result is a supersaturated vernacular with a large degree of variation and loans from superstratum languages which falls far from the standard of the language in question.
\end{abstract}

Keywords: language education policy, minorities, home language, Estonian, Russian

\section{Introduction}

Language planning in education in Estonia to date has seen broader treatment of its formal structure (M. Rannut, Ü. Rannut 1995, Ü. Rannut 2003, M. Rannut 2006, Vare 2002a, 2002b, EMER 2008) with less attention paid to the non-formal environment and the attitudes stemming from it (Ü. Rannut 2005, M. Rannut 2008, M. Rannut, Ü. Rannut 2007, Vihalemm, Masso 2003, Kemppainen, Ferrin 2002). 
This article primarily focuses on this field, investigating the home languages of pupils from Tallinn and examining a variety of factors which influence the language use of students with different ethnic backgrounds and the formation of their linguistic attitudes. Studied in closer detail are pupils from countries which formed part of the former Soviet Union and the home languages they speak, in which the influence of Russification and the displacement of minority languages continue to be observed. The data for the study was collected via questionnaires from 8340 students aged 8 to 12. 34 schools with Estonian as the language of instruction and 19 schools with Russian as the language of instruction took part in the study, which covered all of the districts of the city (M. Rannut, Ü. Rannut 2007).

Home language (cf. Extra, Yagmur 2004) means the language used most frequently or regularly at home by the person being interviewed at the time of the study. As such, a person's home language does not necessarily have to be the same as the language of their community (their everyday language; the one which covers the wider communication network they form part of) or their native language (which could be the language of the country of origin or another language with which they identify themselves). A wide range of other factors was also taken into consideration in the survey. Particular emphasis was given to different aspects of the home languages of pupils from former Soviet countries, where Russification and the loss of ethnic languages of origin are a continuing process. This has not taken place in a linguistically neutral environment, but in conditions of a powerful external influence - in this case a language policy consciously designed to achieve this result - which constitutes the notion of 'Russification'. One of the aims of the study is therefore to describe Russification processes, which continue unabated; while another, as a counterbalance to them, is to highlight the need for and measures of a linguistic support environment and the need for a minority policy in order to ensure the preservation of language diversity and to make languages less endangered.

Russification as a form of linguistic imperialism refers to both an official and unofficial ethnic and language policy which was implemented (and continues to be implemented) by Tsarist Russia, the Soviet Union and today's Russian Federation against national minorities with the aim of russifying other peoples and making them speak Russian.

The direct influence of Russification on Estonians in Estonia during the Soviet occupation was modest; in the census of 1989 just $1 \%$ of Estonians nominated Russian as their native language. The reason for this was first and foremost the wellfunctioning education and language maintenance system, which operated despite strong pressure from Russification policy, and which maintained the high status of Estonian (M. Rannut 1994, 2001, 2004). Nevertheless, other peoples and languages (besides Estonians and Russians) were smothered by Russification, as the Soviet authorities did not allow them to set up any schools with instruction in their own languages or to officially teach the next generation their ethnic languages. (In the Republic of Estonia in the pre-war years this was not only permitted, but promoted by the state.) The result of it was that Russian became the only written language and the primary spoken language among immigrants, especially among Belarusians and Ukrainians as speakers of closely related languages and among mixed marriage families. 
The demographic aspect of Russification in Estonia is very clear: although the census (Statistical Office of Estonia 2000) lists representatives of 142 different ethnic groups claiming 109 different native languages between them, there are only two linguistically and ethnically homogenous groups in Estonia: Estonians, who comprise the majority speaking the titular language; and Russians. This article will not examine Estonia's two largest ethnic groups: indigenous Estonians, who largely managed to preserve their language and culture even during the Soviet occupation; and Russians, who benefited most both linguistically and culturally from the conditions of the period (their numbers increasing twelve-fold between 1944 and 1989, and the number of Russian speakers increasing almost 20 times; see Katus, Sakkeus 1992). The third largest group, Ukrainians, can be more or less divided into two groups based on language: those who have retained Ukrainian as their native language (41\%) and those who have adopted Russian as their first language (57\%). The situation is even worse among Belarusians, where only $29 \%$ consider Belarusian as their native language and 70\% speak Russian as their first language. The dominance of Russian can also be seen among other ethnic groups. It can therefore be said that ethnic identity does not necessarily depend on home language, as this is influenced by a number of factors, including the prestige of the languages spoken around people and the ideologies related to and attitudes towards these languages.

\section{Home language of pupils in Tallinn}

Estonia's pupils have 30 different home languages, comprising $28 \%$ of all of the native languages spoken in Estonia (EHIS, data for 2003). The data collected as part of this study indicates that pupils from the 2nd to the 5 th grades in Estonianand Russian-language schools in Tallinn speak 22 different languages as home languages, which represents $20 \%$ of the total number of languages spoken in Estonia according to the Statistical Office and indicates severe reduction in the number of languages spoken by younger generations. The two main languages spoken at home by pupils are Estonian and Russian. Estonian was spoken as the only home language by $55 \%$ of the pupils surveyed, with $4.9 \%$ speaking Estonian at home in addition to another language. These figures are in line with the proportion of Estonians in Tallinn (54.9\%; Statistical Office 2007). Russian is spoken as the only home language by $39.6 \%$, with a further $4.6 \%$ speaking Russian at home in addition to another language. This figure is significantly larger than the proportion of ethnic Russians in Tallinn (36.5\%), indicating Russification of other ethnic groups. 96\% of the pupils who speak only Russian at home were born in Estonia; 3\% were born in Russia and the remainder in Ukraine (16), Belarus (7), Latvia (7) and other former Soviet countries. $66 \%$ of the mothers and $63 \%$ of the fathers of pupils who only speak Russian at home were born in Estonia; 21\% of parents are from Russia, $6 \%$ from Ukraine and the remainder from former Soviet countries.

The widespread use of Russian as the only home language is a sign of extensive linguistic segregation. Only around one in every ten users of Russian as a home language is to some extent bilingual, though only a marginal proportion of them were born outside Estonia. Two thirds of the parents of Russian-speaking pupils 
were born in Estonia. This means that legally they can no longer be viewed as immigrants or the family members of immigrants, even though their linguistic behaviour continues to indicate otherwise. It is therefore possible in Estonia, where Estonian is the only official language, to preserve Russian as the only home language for generations, which highlights the weakness of Estonia's language and integration policy to date. Just 2\% of pupils speak a language other than Estonian or Russian at home. The most widely used languages in these cases are English, Azerbaijani, Ukrainian, Finnish, Armenian, Italian, Lithuanian, Latvian, Tatar, Swedish and German. Other home languages include Belarusian, Spanish, French, Romanian, Turkish, Bashkir, Georgian, Hebrew, Korean, Hungarian, Setu, Arabic, Chinese, Croatian, Portuguese and a sign language.

The study revealed that $39.6 \%$ of pupils from the respective cohort in Tallinn speak Russian as their only home language and $4.6 \%$ as a second language. Just $3 \%$ of them and $21 \%$ of their parents were born in a republic of the Russian Federation (in this case Chechnya, Tatarstan, Mordovia, Komi, Bashkortostan, Northern Ossetia-Alania and Adygeya) where national languages remain spoken to different extents. Interviews with 224 Russian-speaking pupils revealed that of those who considered themselves to be Russian, one-third had grandparents with a non-Russian background, incorporating very different native languages and national identity. All other ethnic groups showed a declining tendency between generations. In the case of parents with Belarusian origins, $7.2 \%$ of grandparents considered themselves to be Belarusian, but just $2.9 \%$ of the pupils' parents identified themselves in the same way. There were also several times more grandparents with Ukrainian origins (6.5\%) than parents of pupils who identified themselves as Ukrainian (just 1.4\%). This represents a 60\% drop in Belarusians between generations and a 78\% drop in Ukrainians from grandparents to parents. Tatars declined by $33 \%$.

Below we examine some of the larger and more characteristic groups from former Soviet countries in our home language study: Ukrainians, Belarusians, Azerbaijanis and Tatars. What leaves Ukrainians and Belarusians open to particular influence is the fact that both of their languages are part of the Eastern Slavic group of languages and therefore closely related to Russian. They are also close to Russians in terms of predominantly belonging to the Russian Orthodox Church. The second group looks at the predominantly Islamic Azerbaijanis and Tatars, whose languages both form part of the Turkic group of languages, and who are therefore much more removed from Russians in terms of religion and language.

\subsection{Ukrainians}

The Ukrainians who immigrated to Estonia during the Soviet era were already markedly Russified. Of those living in the country in 1989, 65\% $(30,253)$ spoke Ukrainian while $94.2 \%(45,472)$ could speak Russian (Issakov, Tõnurist 1999a: 482-483). The restoration of independence in Estonia saw a fall in the number of Ukrainians by more than a third, although to date they still form the third largest ethnic group in the country: 28,158 Ukrainians, of whom $51 \%$ live in Tallinn (Statistical Office of Estonia 2000). 38\% of those living in Tallinn claim Ukrainian as their native language, compared to $41 \%$ throughout the country; while $61 \%$ of those living in Tallinn name Russian as their native language, compared to $57 \%$ throughout the 
country. According to the Statistical Office, just 108 Ukrainians in Tallinn and 481 in Estonia overall consider Estonian to be their native language.

The number of students with Ukrainian origins in the study is 433. There are only five families in which both the parents and children were born in Ukraine, while there are 35 cases of both parents being born in Ukraine but the children being born in Estonia or elsewhere outside of Ukraine. The majority of families ( 382 or $88 \%$ ) constitute mixed marriages where only one of the parents was born in Ukraine. There are also five families in the study where only the child was born in Ukraine, and families where only the grandparents are from the country. Mixed families in which only one of the parents was born in Ukraine are the most common and that they mostly speak Russian (83\% Russian only; 9\% Estonian and Russian; and 3\% Russian and Ukrainian). However, Russian is also dominant in families where both parents were born in Ukraine: the study revealed that $91 \%$ of parents born in Ukraine and 50\% of new immigrants with Ukrainian origins only speak to their children in Russian.

The study shows that fathers use Ukrainian more than mothers when communicating with their children. $1.2 \%$ of mothers and $2.1 \%$ of fathers with Ukrainian origins used Ukrainian at home as the only language of communication, while $2 \%$ of pupils used it as a second language with their mothers and $3 \%$ with their fathers. At the same time, the number of mothers with Ukrainian origins is higher than that of fathers (244 and 216 respectively). Women can therefore be seen to be more easily assimilated than men, as confirmed in previous interviews (Ü. Rannut 2005: 112-113) and studies (Dorian 1981, Gal 1979), which show that the main figure of influence in the determination of home language is the mother, who also leads the family in its use.

$81 \%$ of families use Russian alone as their home language. A total of only four families (0.9\%) use Ukrainian as their first, i.e. home language, while 22 (5.1\%) use it as a second language. There were a total of 26 pupils in the study who speak Ukrainian as their home language, but 36 parents (14 mothers and 22 fathers). Just $7 \%$ of parents born in Ukraine speak Ukrainian at home, which shows the remarkable loss of the language among first generation immigrants and their assimilation into Russian-speaking society. 75\% of male and female grandparents use Russian alone when communicating with their grandchildren, which shows that language loss has generally already occurred in previous generations. 36 grandmothers (9\%) and 39 grandfathers (9\%) used Ukrainian exclusively when speaking to their grandchildren. A further 22 grandparents (2.5\%) use Ukrainian as a second language. It is notable that a lot more pupils use Ukrainian when speaking to their grandparents than they do when speaking to their parents (81 pupils or $18.7 \%$ and 26 pupils or $6 \%$ respectively). A total of 66 pupils use Ukrainian alone when communicating with their grandmothers or grandfathers, 7 of whom use Ukrainian when speaking to both their grandmother and grandfather. A further 15 pupils use Ukrainian as a second language when communicating with one or both of their grandparents.

The use of Ukrainian decreases from generation to generation. Just 4 pupils (0.9\%) speak Ukrainian exclusively with their brothers and sisters, while 7 pupils (1.7\%) use it as a second language. That these pupils use Russian as a home language can also be seen in the fact that of those questioned, 360 of them study in schools with Russian as the language of instruction and 68 in schools with Estonian as the 
teaching language. The influence of the language of instruction of the school can also be seen on the children's choice of language in communicating with one another. The study shows that the use of Estonian has risen among children studying at schools with Estonian as the language of instruction. Half of the sixty-eight pupils with Ukrainian origins studying in schools with Estonian as the teaching language use Estonian as a first or second language with their brothers and sisters, with $28 \%$ of pupils using Estonian alone, 32\% using Russian alone and none using Ukrainian. Just ten of the 360 pupils with Ukrainian origins studying in schools with Russian as the language of instruction (3\%) speak Estonian as a first or second language. The majority of pupils (84\%) use Russian exclusively at home with their brothers and sisters, while 7 pupils (2\%) use Ukrainian. The teaching language of the school clearly influences linguistic attitudes: the study revealed that just 25 of the 433 pupils with Ukrainian origins prefer to speak Ukrainian, whereas 298 nominated Russian as their preferred language, 69 chose Estonian and 46 said English was their favourite.

The influence of a school's language of instruction on the language of communication between children has been substantiated in previous interviews with and studies into parents and children with Ukrainian origins, where Russian had become the first language of the children at home but the influence of Estonianlanguage schools had also seen the children speaking to each other in Estonian at home (Ü. Rannut 2003: 109-110). Those speaking to their brothers and sisters in Ukrainian were mostly found among new immigrants, where the pupils had older brothers and sisters, both parents were of Ukrainian origin and the whole family used Ukrainian exclusively as their language of communication (Ü. Rannut 2005: 111).

The main factors influencing use of language among Ukrainians are the time of migration (i.e. how many generations of immigrants are involved), mixed families and linguistic attitudes. Interviews with mixed Russian/Ukrainian families in Estonia have shown that the use of Ukrainian as a home language has decreased over the years, as little value is placed on it. As a result, Ukrainian language skills have also suffered: while older children can still speak the language to some extent, younger children no longer understand it.

The study revealed that $19.2 \%$ (83) of pupils with Ukrainian origins communicate in Ukrainian; 18.7\% (81) pupils use Ukrainian when speaking to their grandparents; 6\% (26) use it when speaking to their parents; and 2.5\% (11) use it when speaking to their brothers and sisters. The decline in the use of Ukrainian from one generation to the next is clear to see. Moreover, use of Ukrainian does not necessarily mean competence in Ukrainian. 83 pupils who use Ukrainian at home or when communicating with their grandparents were asked to give an assessment of their Ukrainian language skills. Their responses reflected a downward trend in spoken and written skills: spoken Ukrainian is understood most (and best), with $69 \%$ of pupils responding to this positively, $29 \%$ understanding some and a couple of pupils (2\%) understanding none. Two pupils who claimed not to understand Ukrainian fell into the category of those who are spoken to in Ukrainian by their grandparents but who themselves use Russian when speaking to their grandparents. 57\% of pupils said they could speak Ukrainian; $37 \%$ that they could speak some Ukrainian; and 6\% claimed not to be able to speak any Ukrainian at all, even 
though they are spoken to at home or by their grandparents in Ukrainian. $52 \%$ of pupils said they could read Ukrainian, while $33 \%$ said they could also write in the language. $20 \%$ claimed they could not read the language at all and $31 \%$ claimed they could not write in it. Such results in reading and writing are in fact noteworthy, as no pupils claimed to be learning Ukrainian either at school or elsewhere.

\subsection{Belarusian}

As with Ukrainians, Belarusians mostly began to emigrate to Estonia after World War II. By 1959 their numbers in the country had reached 10,030. After thirty years of Soviet occupation this figure had almost tripled reaching 27,711 by 1989 (Issakov, Tõnurist 1999b: 510). Belarusian was the native language of 8841 (32\%) of them and the second language for a further 4703, while Russian was the native language of $18,591(67 \%)$ and the second language of 8283 , thus revealing a remarkable amount of Russification. Belarusian as a language held very little status, being seen as little more than a dialect and poor cousin of Russian, and it therefore never became a literary language. The Soviet authorities were intolerant of Belarusian culture: those who championed the language and culture were arrested, with some of them sent to hard labour camps, where they died, and some of them exiled. The wave of migration after World War II was the result of Russification policy, which redirected workers of different nationalities to occupied territories where their common language would be Russian. Already weak, the ethnic identity of the Belarusians diminished further under the influence of this forced intermingling and with Russian as the lingua franca, with the result that every consecutive census has seen fewer and fewer people nominating Belarusian as their native language. Just $27 \%$ of the Belarusians in Estonia considered Belarusian to be their native language in the 2000 census. Since the only schools that existed in Soviet times alongside Estonian-language schools were those with Russian as the language of instruction, this deepened the extent of the assimilation of Belarusians into Russian-speaking society and the acceptance of Soviet identity, as a consequence of which they began to class themselves as Russians.

After Estonia regained its independence there was a new national awakening among Belarusians and recognition of the need for them to distinguish themselves from the rest of the Russian-speaking population. As a result, many Belarusians left the country; their numbers in Estonia dropped by more than a third, and of the 16,133 that remain, 7593 (47\%) live in Tallinn. Although a mere $27 \%$ of Estonia's Belarusians consider Belarusian to be their native language and 70\% speak Russian as a first language, more Belarusians are starting to place greater value on their language and culture (Statistical Office of Estonia 2000).

There were 154 pupils (or one of their parents) in this study who were born in Belarus, plus 2 pupils who were born (along with their parents) outside of Belarus, but who speak to their grandparents in Belarusian. Only 3 pupils in this group (1.9\%) use Belarusian in addition to Russian and Estonian at home when communicating with their parents. Russian is predominantly used, with Estonian also used in individual cases, resulting from the choice of school language or the native language of the parents. $86.5 \%$ of families only speak Russian at home, 
while 15 pupils (9.6\%) use Russian as a second language or as the main language of communication, which brings the total number of speakers of Russian as a home language in this group to 150 pupils (96.1\%). It is remarkable to note that only fathers communicate in Belarusian with their children; that in only two cases is Belarusian used exclusively; and that in one case it is only used as a second language after Russian. Russian dominates as the language of communication with both parents and grandparents in $87 \%$ of cases. Just 22 pupils communicate with their parents and grandparents in Belarusian. No pupils use Belarusian when speaking to their brothers and sisters, which is only to be expected given that there are no families in the group in which Belarusian is exclusively spoken. 80\% of pupils (125) only use Russian with their brothers and sisters, while 7 pupils (4\%) use Estonian and the remaining 6\% use Estonian or other languages (English, German) in addition to Russian. It can therefore be claimed that $86 \%$ of pupils speak to their brothers and sisters at home in Russian.

As with the Ukrainian group there was also a marked decline in language skills, with spoken skills faring better than written skills. $65 \%$ of the twenty pupils who use Belarusian understand it and are able to speak it, while $60 \%$ claimed also to be able to read it and 50\% to write in it. None of the 156 pupils studies Belarusian at school or outside of school, and only 8 of them (5\%) expressed an interest in learning it. It can therefore be seen that the use of Belarusian among Estonia's Belarusian community is virtually non-existent, as reflected in the pupils' assessments of their language skills.

In summary, while Belarusians comprise the fourth largest ethnic group in Estonia and 46\% (7938) of them live in Tallinn, Belarusian as a language has basically died out among pupils in the city. Just 22 of the 156 pupils with Belarusian origins involved in the study (14\%) use Belarusian, primarily when communicating with their grandparents. No pupils speak to their brothers or sisters in Belarusian, since only 3 parents use the language as one of their home languages.

\subsection{Azebaijanis}

The third group is Azerbaijanis, who do not form a large ethnic group within Estonia according to Statistical Office figures (2001) but who have nevertheless managed to preserve their language with much greater success than the Ukrainians (see also Mamedov 1999). 1238 Azerbaijanis had come to live in the country by 1989 , of whom 869 (70.2\%) spoke Azerbaijani as their native language. 342 spoke Russian as a first language and 686 as a second language, meaning a total of $83 \%$ of Azerbaijanis used Russian in a lingua franca function. The independence gained by Azerbaijan in 1991 upon the collapse of the Soviet Union and the establishment of Azerbaijani as the only official language in the country of 8 million people has undoubtedly contributed to the preservation of their language today. Another factor influencing preservation both in Azerbaijan and among diaspora communities is religion: whereas the Russian Orthodox faith as one of the most international denominations of Christianity is widespread among Russians, Islam is the religion of $96 \%$ of all Azerbaijanis (80\% of them Shi'a and 20\% Sunni) and forms a major part of their national identity. Census data from 2001 had 880 Azerbaijanis living in Estonia, 57\% of them (505) in Tallinn. 69\% (347) spoke Azerbaijani, 29\% (145) 
Russian and 8\% (4) Estonian as their first language (Statistical Office of Estonia 2000). Compared to the Ukrainians and Belarusians, this is a group which has been much more successful in preserving its native language.

In our study there were 48 pupils in Tallinn with Azerbaijani origins. In five cases both the pupil and his or her parents were born in Azerbaijan (10\%); 13 pupils' parents are both from Azerbaijan (27\%); and 28 pupils (58\%) are part of mixed marriage families where only one of the parents is from Azerbaijan. 13\% of the families speak Azerbaijani as their only home language, with a further $21 \%$ speaking it as a second language (16 pupils in total). 16 pupils (33.3\%) use Azerbaijani when communicating with their parents, of whom $6(12.5 \%)$ use it as their only home language. The language is used to speak to 18 fathers ( $38 \%$ of fathers) and 14 mothers (29.2\% of mothers).

Azerbaijani is the sole home language only of those pupils whose parents were both born in Azerbaijan and who, for the most part, were also born there themselves. These people are therefore new immigrants who value their native language. Estonian is spoken as the only home language by 2 pupils and by a further 2 pupils as a second language ( $8 \%$ in total), as reflected in the choice of school teaching languages. Russian is most dominant in mixed marriage families, where $75 \%$ of pupils (21) use Russian as the only home language when communicating with their parents and $14 \%$ (4) use it as a second language in communicating at home.

Regardless of the fact that their native language has been comparatively well preserved, Azerbaijanis exhibit the same tendency as Ukrainians in that more pupils speak Azerbaijani with their grandparents than with their parents. A total of 20 pupils (42\%) use Azerbaijani to communicate with their grandparents; 13 use the language when speaking to both their grandmothers and grandfathers. It should nevertheless be noted here that the difference between generations is not as great as was observed with the previous groups.

Unlike the groups examined earlier, there is also more communication with brothers and sisters in Azerbaijani. 14.6\% of pupils (7) use Azerbaijani as a second language and 1 pupil uses it as the only language of communication with their siblings. However, more than half of the pupils in this group too $(27,56 \%)$ use Russian, and 10.4\% (5) speak with their brothers and sisters in Estonian, because of their school language.

As with Ukrainians and similar to previous study results (Ü. Rannut 2005), the choice of language used with brothers and sisters is primarily influenced by the language of instruction of the pupils' schools and the resulting language that they use with their peers both at school and outside of school. The study showed that ten of the eleven Azerbaijani pupils studying in Estonian-language schools speak Estonian exclusively with their classmates; outside of school, however, Russian dominates. A similar tendency could be seen in Russian-language schools, where 34 of the 37 pupils use only Russian in school, and 29 pupils also use it as their sole language of communication outside of school.

20 pupils who use Azerbaijani when speaking to their parents or grandparents were asked to give an assessment of their Azerbaijani language skills. As with the Ukrainian pupils, their responses reflected a downward trend in spoken and written skills: $85 \%$ of the pupils understood Azerbaijani and $80 \%$ of them could speak the language, outstripping the same figures for the Ukrainian pupils (69\% of whom claimed to understand the language and $57 \%$ of whom said they could speak it). 
None of the pupils who use Azerbaijani as a home language claimed that they could not speak the language, although one did claim that they could not understand it. 45\% of pupils said they could read and write in Azerbaijani, while 30\% said they could not read the language at all and 35\% said they could not write in it. The fact that some pupils who speak Azerbaijani as their sole home language cannot read in their native language when they start school has also emerged in interviews with both pupils and teachers (M. Rannut, Ü. Rannut 2003).

\subsection{Tatars}

Tatars form the sixth largest ethnic group in Estonia, and like the Azerbaijanis are largely Islamic, different therefore from both Estonians and Russians in terms of religion. Nevertheless, Statistical Office data has only a third of Estonia's Tatars as Muslims, with 8\% subscribing to the Russian Orthodox faith and the majority (58\%) claiming no religion, likely as a result of the atheist propaganda of the Soviet Union. 404 of the 754 Tatar Muslims in Estonia live in Tallinn. The Estonian Islamic Congregation was re-registered in 1989.

The Estonian Islamic Congregation and the Tatar Cultural Society initially overlapped in terms of membership. The Islamic Congregation was restructured in 1994 and set itself the goal of bringing together and organising the activities of all of the Muslims living in Estonia. Among the members of the congregation are people from Azerbaijan, Uzbekistan, Kyrgyzstan, Kazakhstan and other Islamic countries (Estonian Bureau for Lesser-Used Languages (EstBLUL) ${ }^{1}$ ). After World War II the number of Tatars in Estonia grew rapidly, having risen to 4058 by 1989 (Ahmetov, Nisamedtinov 1999: 450). After Estonian regained its independence many of them left the country, and by 2001 their number had dropped by almost half to 2582,1265 of whom (49\%) live in Tallinn. A further 245 live nearby in Maardu. According to the data of the Statistical Office, $50 \%$ of the Tatars in Estonia speak Russian and 47.6\% speak Tatar as their first language. They are therefore ranked higher in terms of their native language than Ukrainians and Belarusians, but lower than Azerbaijanis.

A total of just 13 pupils with Tatar origins were found as part of this study, which is surprisingly few, given the size of the ethnic group in Estonia. None of the pupils were themselves born in Tatarstan; as an exception, they were all born in Estonia. There were also no families where both parents were from Tatarstan, which shows that there are no new immigrants to be found among the group and that mixed marriage families predominate.

From interviews it could be concluded that there may in fact have been more pupils with Tatar origins, as some parents who were born elsewhere in Russia (there are more ethnic Tatars outside of Tatarstan than there are in Tatarstan) consider themselves to be ethnic Tatars but have adopted Russian as the language they use amongst themselves.

5 pupils (38.5\%) use Tatar as one home language when communicating with their parents, while 8 only use Russian at home. The same number of pupils (5) use Tatar when communicating with their grandparents, but three of the five pupils use Tatar in this case as their only language of communication. It can therefore also 
be said of this group that more Tatar is used when communicating with grandparents.

A total of six pupils (46.2\%) speak Tatar as their only language or as a second language when communicating with their parents or grandparents. Numbers-wise this would seem to indicate that the Tatar-language community is diminishing, but in terms of percentages they have in fact managed to maintain their native language better than the other groups examined in this study. The only cause for concern is that Tatar is not used as the sole home language by any family, reflecting its displacement by Russian and the rapid assimilation which took place among the previous generation as a result of Russification and enforced atheism. Here it is important to note the status factor which operated in Russian-speaking environments: the Tatars were particularly badly affected by Russian chauvinism, associated (unfoundedly) with the Mongols of history, as a result of which many attempted to conceal their ethnic identity and, if possible, amended their 'passport nationality' to Russian. In the hierarchy of religious status Islam was also poorly placed and connected with an even greater lack of education and financial retardation than the Russian Orthodox faith. At the same time, these attitudes never existed in Estonian-speaking society.

As with the other ethnic groups, the national language is used as a home language least often in communication between brothers and sisters, which is dominated by Russian. Only one pupil also uses Tatar. This is undoubtedly influenced by the language of instruction of the pupils' schools, since $69 \%$ of the pupils go to Russian-language schools. It should also be noted though that those students who go to schools with Estonian as the language of instruction (31\%) also use Russian for home communication, with again one pupil also using Tatar. The impression gained from comparing home languages and school languages was that children are only placed in Estonian-language schools if Estonian is one of the languages used at home. Since Russian is usually also added to this, it is difficult to determine whether it is a case of the native language of one of the parents or simply use of Estonian as a foreign language related to the children's studies, since Estonian clearly enjoys high status in Estonian-language schools, influencing the attitudes of both children and their parents.

All 6 pupils who use Tatar when communicating with their parents or grandparents claimed to be able to speak and understand the language. However, in terms of reading and writing skills the study showed a similar decreasing tendency to that of other groups. One pupil nevertheless claimed to be able to both read and write in Tatar, while another claimed to be able to do so a little.

\section{Discussion and summary}

The Soviet occupation of Estonia brought with it an all-encompassing policy of Russification whose consequences are continuing to have a negative impact on the sustainability of different national groups. Two larger and more characteristic groups (Ukrainians and Belarusians) and two groups with Islamic backgrounds (Azerbaijanis and Tatars) were compared with the aim of analysing different language loss and preservation factors. 
The social status of the language in the country or state of origin and that country or state's political independence from Russia only affects the group internally, thus producing differences between the Ukrainians and Belarusians and between the Azerbaijanis and the Tatars. It is for this reason that (for example) the Ukrainians, who enjoy greater political independence from Russia and have one national language, have managed to preserve their native language more successfully than the Belarusians, whose country is bilingual and markedly more politically dependent on Russia. Pupils from monolingual Azerbaijan have also maintained their language more effectively than those from Tatarstan, which is bilingual and forms a part of the Russian Federation.

What leaves Ukrainians and Belarusians open to particular influence is the fact that both of their languages are part of the Eastern Slavic group of languages and therefore closely related to Russian. The similarity is increased further by the verbal use of the option used as the home language, which is generally far from the literary standard, with Belarusian/Russian and Ukrainian/Russian patois (known as Trasyanka and Surzhyk, respectively) used in its place. They are also close to Russians in terms of predominantly belonging to the Russian Orthodox church. The lack and uncertainty of specific barriers preserving nationality, but also the lack of the national languages in a number of functions (such as teaching and literary languages), has enabled Russian to become dominant among these ethnic groups and for their native languages to be replaced. In assessing Estonia's Ukrainians it could be said that their language has all but died out under pressure from Russification and that for new life to be breathed into it and for further Russification to be prevented home language classes and groups must be established, especially in the case of such a large group of people. The situation with Belarusian is even direr, having practically disappeared within its own community: just 22 of the 156 pupils with Belarusian origins (14,1\%) use the language, mostly when speaking with grandprents and at a level of quality far removed from the literary norm. The study also revealed that no pupils with Belarusian origins speak to their brothers and sisters nor to their friends in Belarusian. Since $88 \%$ of the pupils go to Russian-language schools, it is natural that $83 \%$ communicate exclusively in Russian at school and outside of school, with the remainder speaking a mixture of Russian and Estonian.

As the preservation of Belarusian is even problematic in Belarus due to strong pressure from Russification (and despite the fact that with an effective language policy it would have more than 10 million speakers!), none of the much-needed support for the language is coming from that direction either. In contrast, the flexing of political muscle that is going on between Ukraine and Russia at the moment and the fact that the Soviet era remained an insufficient period of time to truly russify the Ukrainians means that things are quite different for this ethnic group: national and linguistic identity is being reinforced. The extent to which these nationalist sentiments are reaching Estonia's Ukrainian population is debatable: the results of the 2007 parliamentary elections in Ukraine show that the majority of the Ukrainian community here supports its nation's Russian-minded party. This is a signal of the crossing of a critical line in views, where dominant attitudes are adopted among speakers of an encroaching language even if skills in their own language have been preserved to some extent (Fishman 2001). Given the number 
of pupils with Ukrainian or Belarusian origins and their tendency to live in the same northern Estonian towns and cities and districts of Tallinn, it would make sense to establish classes in support of these groups' languages and cultures. To date this has been very limited, despite a number of events, mainly because parents continue to prefer Russian-language education for their children. Even among the pupils themselves the level of interest in learning the language of their country of origin is modest at best.

The second group examined as part of the study are the Turkic language-speaking and predominantly Islamic Azerbaijanis and Tatars. The objective in studying these groups was to enable an analysis of the linguistic and cultural assimilation due to Russification of ethnic groups religiously and linguistically different from Estonians and Russians and an analysis of the current situation of their languages and the opportunities that exist for preserving them. Slightly fewer than half of the Tatars in Estonia (47.6\%) use Tatar as their first language. They are therefore ranked higher in terms of their native language than Ukrainians and Belarusians, but lower than Azerbaijanis, who are mostly new immigrants. Nevertheless, 6 pupils (38.5\%) of the children with Tatar origins speak Tatar as a first or second language and mostly when communicating with their grandparents. There are no opportunities for learning Tatar at present in Tallinn. The Sunday school activities which have been relaunched are insufficient. Organising proper education in the language is being hindered by the lack of qualified teachers, but no less by the fact that the Tatar alphabet was changed a number of times during the Soviet era, the Arabic alphabet being replaced in the 1920 s with the Latin alphabet and it being replaced in the 1930 s with the Cyrillic alphabet due to Russification. The impression gained from the interviews with Estonia's Tatars was that although the parents use Russian as the only language of communication with their children, they place high value on Tatar and identify themselves with it.

Unlike the Tatars, the Azerbaijanis have their own country of 8 million people and their own national language, which have undoubtedly contributed greatly to the preservation of the language today. However, in spite of their native language remaining well preserved, a loss of Azerbaijani can still be seen to be occurring between generations. The language is used as a first or second home language by $41.7 \%$ of children when speaking with their grandparents, by $33.3 \%$ when speaking with mothers and fathers, and by 8 pupils (17.7\%) when speaking to siblings. Mixed marriages are a significant factor in the loss of Azerbaijani, with $75 \%$ of pupils (21) using Russian as their only home language when communicating with their parents and 14\% (4) using it as a second language in communicating at home. Compared to the Tatars, the main difference would appear to lie in the time of emigration more than the extent of Russification. Azerbaijani is the sole home language only of those pupils whose parents were both born in Azerbaijan and who, for the most part, were also born there themselves.

The results of the study highlight the glaring differences between the two groups: first, Ukrainians and Belarusians; secondly, Azerbaijanis and Tatars. Although Ukrainians and Belarusians form much larger ethnic groups within Estonia, they have not managed to preserve their language anywhere near as successfully as the Azerbaijanis and Tatars. Comparison of the data suggests that language preservation in Estonia and the ability to withstand Russification are most influenced by 
the degree of difference of the language from Russian and the religious difference from the Russian Orthodox faith (and Soviet era atheism).

Also having a negative influence on the preservation of the languages among the younger generation (pupils) in all groups is the language of instruction in schools and the lack of opportunities for the pupils to learn their national languages either at school or outside of it.

Estonia's regaining of its independence has led to a rise in national self-awareness and through it a newfound respect for national language. Despite the different statuses of Russian, the de-Russification trend is the same for all compared to Soviet times. Both the drop in status of Russian in the countries of origin and the favourable attitude of Estonia's language policy to the preservation of languages with small numbers of speakers have changed the linguistic attitudes of new immigrants with different native languages. Interviews with Russian-speaking parents (Ü. Rannut 2005) show that representatives of those national groups who migrated to Estonia during the Soviet era have begun to place higher value on their language and culture, even if their nation remains part of the Russian Federation, and have started to use their native languages as their home languages wherever possible.

Home languages are characterised by their use mainly in the verbal form, with skills in the literary language generally low or even non-existent. Interviews revealed that in preschool preparations parents focus wholly on the language of instruction of the future school (for example Estonian), as a result of which teaching their children to read and write in their native language is not considered imperative. Languages are for the most part learned informally, primarily through communication with parents and/or grandparents. The result is a supersaturated vernacular with a large degree of variation and loans from superstratum languages which falls far from the standard of the language in question.

The member of the family wielding the greatest influence in the determination of home language is the mother, who also uses the language predominantly in the family; the main factor in the determination of the language is the relationship network (function) and status (for a general theoretical treatment see Dorian 1981, Gal 1979). Women can therefore be seen to be more easily assimilated than men, as confirmed in previous interviews (Ü. Rannut 2005: 112-113).

Compared to Western Europe, the extent of mixed marriages between nationalities stands out, often taking in more than three-quarters of the national groups. The reasons behind this are various and mostly connected to the nature of the Soviet system. One was the lack of private ownership and choice of where to live, which did not necessarily allow people to live with people from their own area and which was designed to create city districts with national flavours. The lack of private and state schools (apart from Russian and Estonian ones) and national societies also shepherded young people with different national backgrounds into the same, Russian-language environment of communication and way of thinking, which produced favourable conditions for mixed marriages, which in turn promoted the use of Russian. At the same time, the number of mixed marriages involving Estonians was marginal, accounting for just 6 to $8 \%$ of all marriages.

The influence of Russification in the case of the home languages examined in this study can be seen most prominently in the lack of availability of formal education in people's native languages, which may still allow them to use them as 
spoken languages, but not in their status as literary languages. (There is little point in discussing native language language technology resources in the case of former Soviet non-Russian autochthonous peoples.) Other key factors are the time at which the people emigrated, the extent to which they did so, the size of the group, how dispersed they are, the religious barrier in the case of Islam and respect for it (including for the tradition of bringing a wife from the person's home village in their country of origin or from within their tribe), the negative attitude of Russians towards specific national groups (forcing people to either conceal or flaunt their origins or ethnic identity) and the level of prestige of languages. Arriving in Estonia from somewhere outside of their ethnic territory is itself a sign of people have adopted another language, while mixed marriages are also a catalyst for adopting another language.

The data collected during the study shows that Estonian schools have an important role to play in changing and shaping people's attitudes and values so that solutions other than just a transition to Russian, to date seen as unavoidable, can be found in the homes of pupils with languages other than Estonian in the choice of which language to use at home. Estonian society is also different in terms of its greater ethnic and linguistic tolerance, as a result of which a number of groups here who were persecuted under the Soviet Union (such as the Tatars and people from the Caucasus) no longer feel ashamed of their native languages or ethnic identities. This supports the use and sustainability of a range of home languages.

Studying the use of language and linguistic attitudes of pupils as the younger generation and the connections that exist between them and the use of language of older generations also enables us to assess Estonia's future multicultural development. Such forecasts are generally pessimistic, predicting that the majority of languages will die out completely over the next couple of generations. Customising the current education system to take the needs of home languages into account would create the required support and give new hope for the preservation of linguistic and cultural diversity in Estonia.

\section{References}

Ahmetov, Dajan; Nisamedtinov, Ramil 1999. Tatarlased. - Jüri Viikberg (toim.). Eesti rahvaste raamat. Rahvusvähemused, -rühmad ja -killud. Tallinn: Eesti Entsüklopeediakirjastus, 449-452.

Dorian, Nancy 1981. Language Death: The Language Cycle of a Scottish Gaelic Dialect. Philadelphia: Univ. Penn. Press.

EHIS = Eesti Hariduse Infosüsteem [= National Registry of Estonian Education (with restricted access); former Andmevara]. http://www.ehis.ee (20.02.2010).

Estonian Bureau for Lesser-Used Languages (EstBLUL). Tatar language, http://www.estblul. ee/ENG/Languages/tatar.html (20.02.2010).

Extra, Guus; Yagmur, Kutlay (Eds.) 2004. Urban Multilingualism in Europe. Immigrant Minority Languages at Home and School. Clevedon: Multilingual Matters.

Gal, Susan 1978. Peasant men can't get wives: Language change and sex roles in a bilingual community. - Language in Society, 7, 1-16. doi:10.1017/So047404500005303

Issakov, Sergei; Tõnurist, Igor 1999a. Ukrainlased. - Jüri Viikberg (toim.). Eesti rahvaste raamat. Rahvusvähemused, -rühmad ja -killud. Tallinn: Eesti Entsüklopeediakirjastus, $479-495$. 
Issakov, Sergei; Tõnurist, Igor 1999b. Valgevenelased. - Jüri Viikberg (toim.). Eesti rahvaste raamat. Rahvusvähemused, -rühmad ja -killud. Tallinn: Eesti Entsüklopeediakirjastus, 508-515.

Katus, Kalev; Sakkeus, Luule 1992. Foreign-born Population in Estonia. Rahvastiku-uuringud. Seeria B, 19. Tallinn: Eesti Kõrgkoolidevaheline Demouuringute Keskus.

Kemppainen, Raija; Ferrin, Scott Ellis 2002. Parental choice and language-of-instruction policies and practices in Estonia. - Education and Urban Society, 35 (1), 76-99. doi:10.1177/001312402237215

Mamedov, Vidadi 1999. Aserbaidžaanid. - Jüri Viikberg (toim.). Eesti rahvaste raamat. Rahvusvähemused, -rühmad ja -killud. Tallinn: Eesti Entsüklopeediakirjastus, $33-36$.

Rannut, Mart 1994. Beyond linguistic policy: the Soviet Union versus Estonia. - Tove Skutnabb-Kangas, Robert Phillipson (Eds.) in collaboration with Mart Rannut. Linguistic Human Rights: Overcoming Linguistic Discrimination. Berlin/New York: Mouton de Gruyter, 179-208.

Rannut, Mart 2001. Eesti kirjakeelest ja selle kvaliteedist. - Sirje Mäearu, Peeter Päll (toim.). Keelekorralduse konverents 18.-19. novembril 1999, ettekanded. Tallinn: Eesti Keele Sihtasutus, 75-106.

Rannut, Mart 2004. Language Planning in Estonia: Past and Present. Working Paper 16. CIEMEN/Mercator. http://www.ciemen.org/mercator/pdf/wp16-def-ang.PDF (1.03.2010).

Rannut, Mart 2006. The role of education in reversing language shift in Estonia. - John Kirk (Ed.). Belfast Studies in Language, Culture and Politics. Belfast: Queen's University.

Rannut, Mart; Rannut, Ülle 1995. Bilingualism - a step towards monolingualism or multilingualism? - Tove Skutnabb-Kangas (Ed.). Multilingualism for All. European Studies on Multilingualism, 4. Lisse: Swets and Zeitlinger, 183-198.

Rannut, Ülle 2003. Muukeelsete õpilaste integreerimine eesti koolis. Õpik kõrgkoolile ning muukeelsete õpilastega töötavale aine- ja klassiõpetajale. Tallinn: TPÜ Kirjastus.

Rannut, Ülle 2005. Keelekeskkonna mõju vene õpilaste eesti keele arengule ja integratsioonile Eestis. Tallinna Ülikool. Humanitaarteaduste dissertatsioonid, 14. Tallinn: TLÜ kirjastus.

Rannut, Ülle; Rannut, Mart 2007. Tallinna õpilaste kodukeeled. - Haridus, 3-4, 7-10.

Statistical Office of Estonia 2000 = Statistikaamet 2000. Statistika andmebaas: rahvaloendus 2000. Tallinn: EV Statistikaamet. http://pub.stat.ee/px-web.2001/Database/ Rahvaloendus/databasetree.asp (20.02.2010).

Vare, Silvi 2002a. Eesti keel vene koolis I. Eesti keele õpetamine vene üldhariduskoolis. http://www.hm.ee/index.php?popup=download\&id=3972 (20.02.2010).

Vare, Silvi 2002b. Eesti keel vene koolis II. Eesti keele kasutamine vene üldhariduskoolis.http:// www.hm.ee/index.php?popup=download\&id=3971 (20.02.2010).

Vihalemm, Triin; Masso, Ann 2003. Identity dynamics of Russian-speakers of Estonia in transition period. - Journal of Baltic Studies, 34 (1), 92-116. doi:10.1080/01629770200000271

\footnotetext{
Mart Rannut (Tallinn University). His research interests cover: language policy and planning, linguistic imperialism, second language acquisition.

mart.rannut@tlu.ee
}

Ülle Rannut (Tallinn University). Her research interests cover several domains in sociolinguistics: language education policy, adaptation policies for immigrants and their children, second language acquisition issues, cross-cultural communication.

yrannut@tlu.ee 


\section{MITTE-EESTI ÕPILASTE \\ VENESTUMINE TALLINNAS}

Mart Rannut, Ülle Rannut

Tallinna Ülikool

Artiklis analüüsitakse Tallinna II-V klassi õpilaste kodukeeli, nende kvaliteeti ja kasutust. Võrreldakse kahte suurimat rühma (ukrainlased ja valgevenelased) ja kahte islami taustaga rühma (aserbaidžaanid ja tatarlased), et analüüsida keele säilimise ja kao faktoreid. Kuigi ukrainlased ja valgevenelased on arvuliselt palju suuremad, ei ole nad suutnud säilitada oma keelt nii edukalt kui aserbaidžaanid ja tatarlased. Andmete võrdlus näitab, et keele säilimist ja vastuseisu venestumisele on võimaldanud vene keelest erinevuse määr ja usuline erinevus vene õigeusust ning Nõukogude aja ateismist. Kodukeeli iseloomustab peamiselt suuline kasutus, samas kui kirjaoskus neis on tagasihoidlik või puudub täiesti. Keeli õpitakse tavaliselt mitteformaalselt, põhiliselt vanemate ja vanavanematega suheldes. Tulemuseks on teistest keeltest mõjutatud tugevalt varieeruv ning laenudega küllastunud kõnekeel, mis on kaugel vastavast kirjakeelest.

Võtmesõnad: hariduse keelepoliitika, rahvusrühmad, kodukeel, eesti keel, vene keel 